\title{
VIDURINIO MOKYKLINIO AMŽIAUS MOKSLEIVIŲ SOCIALINĖ ADAPTACIJA KŪNO KULTŪROS PAMOKŲ METU
}

\author{
Romualdas Malinauskas, Šarūnas Klizas, Šarūnas Šniras \\ Lietuvos kūno kultūros akademija, Kaunas, Lietuva
}

\begin{abstract}
Romualdas Malinauskas. Profesorius socialinių mokslų daktaras. Lietuvos kūno kultūros akademijos Sporto pedagogikos ir psichologijos
\end{abstract} katedros vedèjas. Mokslinių tyrimų kryptis — sporto pedagogų ir sportininkų socialinio psichologinio rengimo ypatumai.

\section{SANTRAUKA}

Straipsnyje keliamas probleminis klausimas: kokia vidurinio mokyklinio amžiaus moksleiviu (berniuku ir mergaičiu) socialinè adaptacija kūno kultūros pamokų metu. Tikrinama hipotezé, ar berniuku socialinè adaptacija kūno kultūros pamoku metu geresnè nei mergaičiu.

Tyrimo tikslas - ištirti vidurinio mokyklinio amžiaus moksleiviu socialinę adaptacija kūno kultūros pamoku metu. Uždaviniai: 1) atskleisti moksleiviu (mergaičiu ir berniuku) teigiama savęs vertinima kaip socialinès adaptacijos per kūno kultūros pamokas rodiklį; 2) ištirti moksleiviu (mergaičiu ir berniuku) pasitikejjima savimi kaip socialinès adaptacijos per kūno kultūros pamokas rodikli.

Apklausai buvo pasitelkta H. Rozenbergo metodika teigiamo savęs vertinimo (savigarbos) lygiui nustatyti ir modifikuotas V. Stolino klausimynas pasitikejjimui savimi ivertinti. Matematinès statistikos hipotezèms (vidurinio mokyklinio amžiaus mergaičiu ir berniuku skirtumu patikimumui) patikrinti buvo taikomas $\chi^{2}$ kriterijus. Tiriamaja imtí sudare 306 7-9 klasiu respondentai: 154 mergaitès ir 152 berniukai. Tyrimas atliktas Kauno „Purienu“, „, Versmés “ vidurinèse mokyklose ir Kauno Maironio gimnazijoje.

Tyrimo metu kelta hipotezè, kad berniuku socialinė adaptacija kūno kultūros pamoku metu geresnè nei mergaičiu. iš dalies pasitvirtino, nes buvo nustatyta, kad vidurinio mokyklinio amžiaus berniukai ir mergaitès statistiškai patikimai $(p<0,05)$ skiriasi pagal pasitikèjima savimi: berniukai savimi pasitiki labiau nei mergaitès. Mažai pasitiki savimi 11,69\% mergaičiu, labai pasitiki - 30,52\%. 35,53\% berniuku labai pasitiki savimi, o 3,95\% ju yra žemo pasitikejjimo savimi lygio. Pasitelkus $\chi^{2}$ kriteriju paaiškejo, kad nèra statistiškai patikimo skirtumo tarp vidurinio mokyklinio amžiaus berniuku ir mergaičiu pagal teigiama savęs vertinima, kaip socialinès adaptacijos per kūno kultūros pamokas rodikli $(p>0,05)$.

Raktažodžiai: socialinè adaptacija, savęs vertinimas, pasitikejjimas savimi, vidurinis mokyklinis amžius.

\section{IVADAS}

A nalizuojant pastarujų metu publikacijas ir tyrimus galima konstatuoti, kad vidurinio mokyklinio amžiaus moksleivių socialinès adaptacijos kūno kultūros pamokų metu problema kelia vis didesni pedagogų susirūpinimą. Vaikai, kurie sunkiai adaptuojasi mokykloje, išgyvena labai sudètingą situaciją. Dèl mokyklinès dezadaptacijos formuojasi ar net atsiranda emociniu sutrikimų, kurie neigiamai veikia asmenybès raidą, motyvaciją, elgesi ir todèl dar labiau apsunkina vaiko tolesnès adaptacijos eigą (Griciūtè, 1999).

Socialinè adaptacija - aktyvus individo prisitaikymas prie besikeičiančios aplinkos, kintančiu gyvenimo sąlygų (Leonavičius, 1993). Literatūroje (Laak et al., 2003; Juodraitis, 2004) nurodoma, kad teigiamas savęs vertinimas ir pasitikejjimas savimi yra pagrindiniai socialinès adaptacijos rodikliai. Teigiamas savęs vertinimas ir pasitikè- 
jimas dažniausiai atsiranda tada, kai moksleiviai, isitraukę i veiklą, gali daryti realius sprendimus, kurti savo darbo įvertinimo kriterijus (Tilindienè, 2000; Poderiené, Janonyte, 2006).

Savęs vertinimas suvokiamas kaip tam tikra savimonès vystymosi pakopa ar komponentas, kuris jungia asmenybès žinias apie save ir požiūrị i save (Beresnevičienè, Andziulytė, 2004). Ivairiais amžiaus tarpsniais kitų žmonių ivertinimas nevienodai veikia žmogaus požiūrị i save. Su amžiumi ši įtaka dažniausiai mažeja. Be to, bejgant metams, keičiasi ir tos žmonių grupès, kurių nuomonè labiausiai veikia žmogaus socialinès adaptacijos lygi (Beresnevičienè, Andziulytė, 2004; Andziulytè, Beresnevičienè, 2005).

Daug dèmesio dabar skiriama sportuojančių moksleivių socialinių igūdžių tyrimams. Atskleista, kad dažniausia visu psichosocialiniu problemu priežastis - nepakankama asmenybès socialinè branda, t. y. nepakankami socialiniai igūdžiai (Merrell, 2001; Šniras, Malinauskas, 2006 a). Pagrindiniai dalykai, kurių vaikai ir paaugliai stokoja, tai: geresnis savęs vertinimas, orumas, gebejimas kontroliuoti emocijas, iveikti itampa, nerima, konstruktyviai spręsti konfliktus ir kylančias problemas (Šniras, Malinauskas, 2006 b). Nurodoma, kad socialinių igūdžių stoka bei socialinès adaptacijos problemos vaikysteje ir paauglysteje dažniausiai sukelia psichikos sveikatos problemas vėlesniame gyvenime, todèl vidurinio mokyklinio amžiaus moksleivių socialinès adaptacijos tyrimai išlieka aktualūs.

Pastaruoju metu atsirado tyrimu, kuriuose analizuojami paauglių socialiniai gebejimai (Vyšniauskytė-Rimkienè, Kardelis, 2004 a, 2004 b). Tai, kad socialiniai gebėjimai lengvai nesikeičia, o jų lavinimas ne visada leidžia igytą patirtị transformuoti i realias gyvenimo situacijas, irodo šios srities tyrimų svarbą. Vadinasi, jei socialinės adaptacijos mokykloje klausimais dar galima aptikti mokslo darbų, tai duomenų apie socialinę adaptaciją per kūno kultūros pamokas dar stokojama. Todèl kyla probleminis klausimas: kokia vidurinio mokyklinio amžiaus moksleivių (berniukų ir mergaičių) socialinè adaptacija kūno kultūros pamokų metu.

Hipotezè: berniukų socialinè adaptacija kūno kultūros pamoku metu geresnè nei mergaičių.

Tyrimo tikslas - ištirti vidurinio mokyklinio amžiaus moksleivių socialinę adaptaciją per kūno kultūros pamokas.

\section{Tyrimo uždaviniai:}

1. Atskleisti moksleivių (mergaičiu ir berniukų) teigiamą savęs vertinimą, kaip socialinès adap- tacijos per kūno kultūros pamokas rodikli.

2. Ištirti moksleiviu (mergaičių ir berniuku) pasitikejjimą savimi, kaip socialinès adaptacijos per kūno kultūros pamokas rodiklį.

\section{TYRIMO METODIKA IR ORGANIZAVIMAS}

Buvo tiriami moksleiviai iš Kauno mokyklu. Tyrimui moksleiviai atrinkti tikimybinès (dvipakopès mechaninès) atrankos būdu. Atsitiktinai atrinktos mokyklos ir atliktas ištisinis klasiu, kuriose mokosi vidurinio mokyklinio amžiaus moksleiviai, tyrimas. Tiriamają imti sudare 306 7-9 klasiu respondentai: 154 mergaitès ir 152 berniukai. Tyrimas atliktas Kauno „Purienu““, „Versmès“ vidurinèse mokyklose ir Kauno Maironio gimnazijoje. Moksleiviai buvo tiriami kūno kultūros pamoku metu ir jiems nurodyta, kad vertintu save ir savo pasitikejimą tokị, koks yra kūno kultūros pamokų metu.

Apklausos metu buvo naudota H. Rozenbergo metodika teigiamo savęs vertinimo lygiui nustatyti (Rosenberg, 1989) ir modifikuotas V. Stolino klausimynas pasitikejjimui savimi įvertinti (Райгородский, 2000).

H. Rozenbergo metodiką teigiamo savęs vertinimo (savigarbos) lygiui nustatyti sudaro 10 teiginių, kurie apibūdina asmens būseną. Tiriamiesiems reikejo įvertinti kiekvieną teigini pažymint vieną iš keturių atsakymo variantų (visiškai sutinku, sutinku, nesutinku, visiškai nesutinku). I 1, 2, 4, 6, 7 klausimus atsakius „visiškai sutinku“ skiriami 3 balai, ,sutinku“ -2 , „nesutinku“ -1 , ,visiškai nesutinku“ -0 balu. I 3, 5, 8, 9, 10 klausimus atsakius „visiškai sutinku“ skiriama 0 balu, ,sutinku“ -1 , „nesutinku“ -2 , „visiškai nesutinku“ -3 balai. Rezultatai vertinami taip: iki 10 balų — žemas savęs vertinimas; 11 20 balu — vidutinis savęs vertinimas; $21-30$ balų - aukštas savęs vertinimas).

Modifikuotą V. Stolino klausimyną pasitikejjimui savimi tirti sudare 14 klausimu. Tiriamieji, atsakydami i klausimus, turejjo rinktis vieną iš dviejų atsakymo variantų: ,taip“ arba „,ne“. Surinkti balai buvo perskaičiuojami standartiniais vienetais stenais. Interpretuojant gautus duomenis, buvo remtasi šiais metodikos kriterijais: $1-3$ stenai reiškia mažą pasitikèjimą savimi; $4-7$ stenai vidutinį; 8-10 stenu — puikų ivertinimą, rodanti didelį pasitikèjimą savimi, ịsivaizdavimą save kaip savarankišką, valingą, energingą žmogų, turintį už ką save gerbti. 
Balai i standartinius vienetus stenus buvo transformuojami taip: 0 balu arba 1 balas -1 stenas, 2 balai -2 stenai, $3-4$ balai -3 stenai, 5-6 balai -4 stenai, $7-9$ balai -5 stenai, 10 balu -6 stenai, $11-12$ balu -7 stenai, 13 balų -8 stenai, 14 balų -10 stenų.

Metodiku patikimumas patikrintas pasitelkus Kronbacho alfa rodikli $(0,73)$.

Matematinès statistikos hipotezèms (skirtumo patikimumui tarp vidurinio mokyklinio amžiaus mergaičiu ir berniuku) patikrinti buvo taikomos $\chi^{2}$ kriterijus.

\section{REZULTATAI}

Tiriant pagal H. Rozenbergo metodiką paaiškèjo, kad skirtumas tarp berniukų ir mergaičiu pagal teigiamą savęs vertinimą kūno kultūros pamoku metu yra statistiškai nepatikimas $\left(\chi^{2}(2)=0,66\right.$; $\mathrm{p}>0,05)$ (žr. lent.).

Apskaičiavus santykini dažni (procentus) nustatyta, kad vidurinio mokyklinio amžiaus moksleiviams kūno kultūros pamokų metu būdingiausias yra vidutinis savęs vertinimas. Taip save vertina pusė tirtų mergaičių ir berniukų. Kūno kultūros pamokų metu aukštai save vertina $40,91 \%$ mergaičiu ir $44,74 \%$ berniuku, o žemai - 4,55\% mergaičiu ir $3,29 \%$ berniuku. Skirtumas tarp mergaičiu ir berniukų pagal teigimą savęs vertinimą per kūno kultūros pamokas yra statistiškai nepatikimas, nes $\chi^{2}(2)=0,66(p>0,05)$. Vadinasi, tiek berniukai, tiek mergaitès kūno kultūros pamokų metu save vertina vienodai.

Ištyrus vidurinio mokyklinio amžiaus moksleivių pasitikejjimą savimi kūno kultūros pamoku metu buvo nustatyta, kad 57,79\% mergaičiu ir $60,53 \%$ berniuku savimi pasitiki vidutiniškai (žr. pav.). Mažo pasitikejimo savimi yra 11,69\% mergaičių, didelio pasitikèjimo - 30,52\%. 35,53\% berniuku labai pasitiki savimi, o 3,95\% berniukų būdingas žemas pasitikèjimo savimi lygis.

Tyrimai atskleide, kad vidurinio mokyklinio amžiaus berniukai kūno kultūros pamokų metu savimi pasitiki labiau nei mergaitès, nes pasitelkus $\chi^{2}$ kriteriju nustatytas skirtumas tarp berniuku ir mergaičių pagal pasitikèjimą savimi yra statistiškai patikimas $\left(\chi^{2}(2)=6,52 ; p<0,05\right)$.

\section{REZULTATUQ APTARIMAS}

Kūno kultūra turi didelę reikšmę vidurinio mokyklinio amžiaus moksleivių socialinei adaptacijai. Dèl daugelio priežasčių kūno kultūros pamokos yra puiki galimybè sudominti vaikus fizine veikla. Tyrimai (Bobrova, 2002) rodo, kad kai kūno kultūros pamokų metu yra noras nuolat
Lentelè. Vidurinio mokyklinio amžiaus moksleivių skirstinys pagal teigiamą savęs vertinimą kūno kultūros pamokų metu (skaičiais ir procentais)

\begin{tabular}{|c|l|l|l|l|}
\hline \multirow{2}{*}{ Tiriamieji } & \multicolumn{3}{|l|}{ Teigiamo savęs vertinimo lygis per kūno kultūros pamokas } \\
\cline { 2 - 5 } & Žemas & Vidutinis & Aukštas & $\begin{array}{c}\chi^{2} \text { (2) reikšmè ir pati- } \\
\text { kimumo lygmuo }\end{array}$ \\
\hline Mergaitès (n=154) & $7(4,55)$ & $84(54,55)$ & $63(40,91)$ & \\
\hline Berniukai $(\mathrm{n}=152)$ & $5(3,29)$ & $79(51,97)$ & $68(44,74)$ & $\chi 2(2)=0,66 ; \mathrm{p}>0,05$ \\
\hline
\end{tabular}

Pav. Tiriamųjų skirstinys pagal pasitikèjimą savimi per kūno kultūros pamokas

Pastaba. $p<0,05$ - tarp mergaičių ir berniukų.

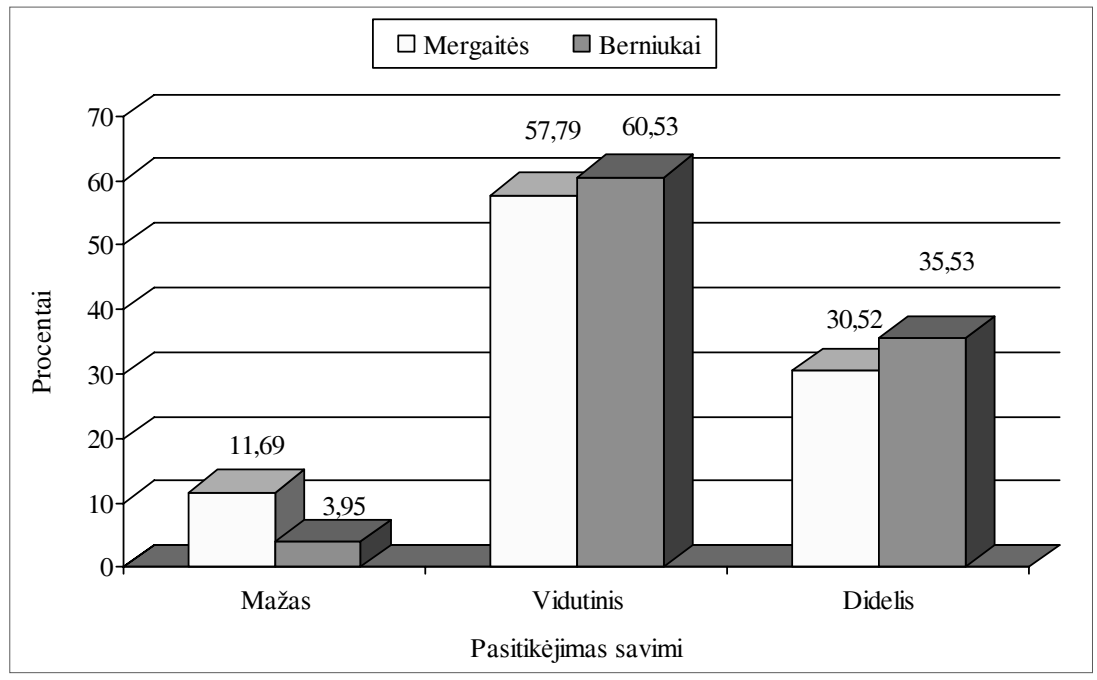


tobulèti, jausti pasitenkinimą fizine veikla, tik tada kūno kultūra igauna pedagoginę prasmę ir vertę. Kadangi kūno kultūra glaudžiai siejasi su daugeliu žmogaus savybiu — dora, pasitikèjimu savimi, savęs realizavimu, savigarba - tai ji padeda stiprinti moksleivių socialinę adaptaciją (Palujanskiené, 2003).

Tyrimo metu kelta hipotezè, kad berniuku socialinè adaptacija per kūno kultūros pamokas geresnè nei mergaičių, iš dalies pasitvirtino, nes berniukai per šias pamokas labiau pasitiki savimi. Panašūs rezultatai gauti, kai buvo tiriami sportuojantys vaikinai ir merginos (Malinauskas, Malinauskienè, 2007): nustatyta, kad sportuojančiu vaikinų psichikos sveikata geresnè $(p<0,05)$ negu tokio paties amžiaus sportuojančiu merginu. Tyrimo metu nepasitvirtino prielaida, kad berniukai per kūno kultūros pamokas save vertina geriau. Todèl galima teigti, kad tiek vidurinio mokyklinio amžiaus mergaitès, tiek berniukai vienodai vertina savo fizinius gebėjimus kūno kultūros pamokų metu. Šio tyrimo duomenys skyrèsi nuo R. Puniškienès ir S. Laskienès (2006) gautujų, kuriais išryškèjo statistiškai patikimas skirtumas $(p<0,05)$ tiek tarp sportuojančių berniuku ir mergaičiuc, tiek tarp nesportuojančiuju. Abiem atvejais berniukai save vertino geriau nei mergaitès.
Šio tyrimo rezultatai parodè, kad berniukai atsakingai žiūri ị per kūno kultūros pamokas pasiektus rezultatus, labiau pasitiki savimi. Taip yra galbūt dèl to, kad berniukai kūno kultūros pamoku metu deda didesnes pastangas nei mergaitès (Bobrova, 2002). Sutinkame ir su S. Šukio (2003) teiginiu, kad dèl brandos skirtumų berniukai, lyginant su mergaitemis, yra agresyvesni, priima drąsesnius sprendimus tiek sportinès veiklos, tiek kasdienio gyvenimo situacijomis, todèl ju pasitikejjimas per kūno kultūros pamokas yra didesnis. Mažai žinoma, kokie yra kiti vidurinio amžiaus moksleivių socialinès adaptacijos rodikliai (pvz., gebejjimas kontroliuoti emocijas, teigiamas kitu vertinimas). Tai galètu būti tolesniu tyrimu objektas.

\section{IŠVADOS}

1. Neaptikta patikimo skirtumo tarp vidurinio mokyklinio amžiaus berniukų ir mergaičiu pagal teigiamą savęs vertinimą, kaip socialinès adaptacijos per kūno kultūros pamokas rodikli $(\mathrm{p}>0,05)$.

2. Nustatyta, kad vidurinio mokyklinio amžiaus berniukai ir mergaitès patikimai $(\mathrm{p}<0,05)$ skiriasi pagal pasitikejjimą savimi: berniukai pasitiki savimi labiau nei mergaitès.

\section{LITERATŪRA}

Andziulytė, I., Beresnevičienè, D. (2005). Lietuvos paaugliu beviltiškumo jausmas ir savivertè. Jaunuju mokslininku darbai. Socialiniai mokslai. Psichologija, 1, 172179.

Bobrova, L. (2002). Šiuolaikinès pradinukų kūno kultūros ugdymo kryptys. Pradinis ugdymas, 3, 54-56.

Beresnevičienè, D., Andziulytè, I. (2004). Paauglių savęs vertinimo ypatumai. Ugdymo psichologija, 11-12, $125-133$.

Griciūtè, A. (1999). Mokyklinès dezadaptacijos ir emocijų tarpusavio itakos klausimai jaunesniame mokykliniame amžiuje. Socialiné-psichologiné adaptacija ir švietimo sistema: moksliniu straipsniu rinkinys. 1 knyga. Kaunas: VDU. P. $104-111$.

Juodraitis, A. (2004). Asmenybés adaptacija: kintamuju sqveika. Šiauliai: ŠU.

Laak, J., De Goede, M., Aleva, L. et al. (2003). Incarcerated adolescent girls: Personality, social competence, and delinquency. Adolescence, 38 (150), 251-266.

Leonavičius, J. (1993). Sociologijos žodynas. Vilnius: "Academia“.

Malinauskas, R., Malinauskienė, V. (2007). Sportuojančių jaunuoliu psichikos sveikata ir vidinè darna. Sveikatos mokslai, 3 (50), 936-938.

Merrell, K. W. (2001). Assessment of children's socia skills: Recent developments, best practices, and new directions. Exceptionalist, 9 (1), 3-18.

Palujanskienè, A. (2003). Savęs vertinimo ir savijautos sąsajos ugdymo procese. Ugdymas. Küno kultūra. Sportas, $4,41-45$.

Poderienè, G., Janonytè, N. (2006). Mokytojo itaka mokiniu adaptacijos procesui. Pedagogika, 82, 73-79.

Puniškienè, R., Laskienė, S. (2006). Sportuojančiu paaugliu vertybinių orientacijų, asmenybès savybių ir savigarbos ypatumai. Sporto mokslas, 4 (46), 48-54.

Rosenberg, M. (1989). Society and The Adolescent SelfImage. Princeton, NJ: Princeton University Press.

Šniras, Š., Malinauskas, R. (2006 a). Jaunujų krepšininkų varžybiniu psichologiniu igūdžiu lygio kaita dèl ugdymo programos poveikio. Sporto mokslas, 2 (44), 31-36.

Šniras, Š., Malinauskas, R. (2006 b). Miestu ir rajonų krepšinio sporto mokyklu moksleiviu socialiniu igūdžiu raiška. Ugdymas. Kūno kultūra. Sportas, 4 (63), 111-117.

Šukys, S. (2003). Agresyvumą sportinèje veikloje lemiantys veiksniai. Ugdymas. Küno kultūra. Sportas, 4 (49), $70-79$

Tilindiene, I. (2000). Sportine veikla kaip paauglio santykio su savimi formavimosi sqlyga: daktaro disertacija. Kaunas: LKKA.

Vyšniauskytė-Rimkienė, J., Kardelis, K. (2004 a). Pa- 
augliu socialinès kompetencijos raiška. Pedagogika, 71, $85-90$.

Vyšniauskytė-Rimkienė, J., Kardelis, K. (2004 b). Paauglių socialinių gebejimų lavinimo efektyvumo vertinimas.
Ugdymas. Kūno kultūra. Sportas, 3 (53), 83-88.

Райгородский, Д. Я. (2000). Практическая псисходиагностика. Методики и тесты: учебное пособие. Самара: Издательский дом «Бахрах».

\title{
SOCIAL ADJUSTMENT AMONG STUDENTS OF MIDDLE SCHOOL AGE DURING PHYSICAL EDUCATION LESSONS
}

\author{
Romualdas Malinauskas, Šarūnas Klizas, Šarūnas Šniras \\ Lithuanian Academy of Physical Education, Kaunas, Lithuania
}

\begin{abstract}
The paper strives to answer the question what social adjustment among students of middle school age is during physical education lessons. The aim of this study was to examine the social adjustment among students of middle school age during physical education lessons. Research tasks: 1) to disclose self-esteem among students (boys and girls) of middle school age during the lessons of physical education; 2) to define selfconfidence among students (boys and girls) of middle school age during the lessons of physical education.

The organization and methods of the research. The sample consisted of 306 students of middle school age (154 females and 152 males). The research was carried out in Kaunas Purienu and Versmès secondary schools, and Kauno Maironio gymnasium. The measure of self-esteem included the Rosenberg scale. The measure of self-confidence level involved Stolin questionnaire. The statistical hypotheses were tested by applying the $\chi^{2}$ test.

The results of the research. After the analyses we established that during the lessons of physical education the male students of middle school age were more self-confident than the girls $(\mathrm{p}<0.05)$. Low self-confidence was characteristic of $11.69 \%$ of girls, high self-confidence was characteristic of $30.52 \%$ of girls. $35.53 \%$ of boys assessed their self-confidence as low and $3.95 \%$ of boys assessed their self-confidence as high. During the research it was found that the self-esteem of boys and girls during physical education lessons was adequate. After applying $\chi^{2}$ test, it was established that there were no statistically significant differences in boys and girls in respect with self-esteem $(\mathrm{p}>0.05)$.
\end{abstract}

Keywords: social adjustment, self-esteem, self-confidence, middle school age.

Gauta 2008 m. gegužès $1 \mathrm{~d}$.

Received on May 1, 2008

Priimta $2008 \mathrm{~m}$. birželio $18 \mathrm{~d}$.

Accepted on June 18, 2008

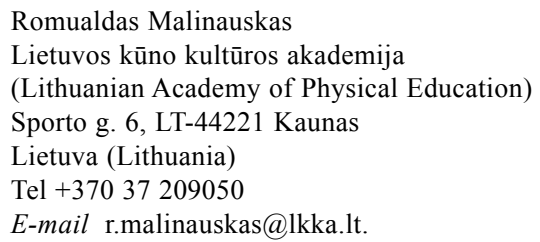

